\title{
Lymphoepithelial Cyst of the Pancreas: A Case Report
}

\author{
Mi Hye Yu \\ Department of Radiology, Konkuk University Medical Center, Konkuk University School of Medicine, Seoul, Korea
}

Lymphoepithelial cyst of the pancreas is a rare, non-malignant lesion with a good prognosis. It is filled with keratinized material, lined by squamous epithelium, and surrounded by lymphoid tissue. The imaging appearance of lymphoepithelial cyst varies and sometimes similar to other pancreatic lesions. Therefore, the preoperative imaging diagnosis of the lymphoepithelial cyst is difficult. We present a case of surgically diagnosed lymphoepithelial cyst of the pancreas focused on MR imaging features.

Keywords: Pancreas; Pancreatic cyst; Magnetic resonance imaging; Diffusion-weighted imaging

\section{Introduction}

Lymphoepithelial cyst of the pancreas is very rare, benign pancreatic cyst (1). Because it has a good prognosis, it is important to differentiate accurately this lesion from other more aggressive pancreatic neoplasm for an appropriate treatment strategy. However, the imaging appearance of lymphoepithelial cyst varies and sometimes similar to other pancreatic lesions $(1,2)$. Furthermore, studies regarding the imaging appearance of lymphoepithelial cyst are limited to case report or small case series (3-10). Thus, it is difficult to make a definitive diagnosis of lymphoepithelial cyst solely on the findings of preoperative imaging (2). Recently, MRI features including diffusion-weighted imaging (DWI) of the pancreatic lymphoepithelial cyst have been reported in a few case reports $(11,12)$. Herein, we present a case of surgically confirmed pancreatic lymphoepithelial cyst focused on MR imaging features.

\section{Case Report}

A 53-year-old men was referred to our institution for evaluation of incidentally detected pancreas mass. During the preoperative evaluation of the rectal cancer, the pancreatic mass was founded. He had undergone low anterior resection and followed adjuvant chemotherapy for rectal cancer on 2018. Except this medical history, he has no other underlying disease such as diabetes, hypertension. He has no specific symptoms related to the pancreatic lesion.

On pre-operative contrast-enhanced CT which was taken on 2018 April, a $3.3 \mathrm{~cm}$ sized, lobulated lowattenuated cystic lesion was found at the upper portion of the pancreas tail (Fig. 1A). The cystic lesion revealed mild rim enhancement and internal septa was suspicious on CT. However, there was no enhancing solid component within the cystic lesion. The remaining pancreas parenchyma demonstrated no swelling, atrophic change, calcification,

\footnotetext{
Received: May 18, $2021 \quad$ Revised: June 23, 2021 Accepted: June 24, 2021 Correspondence: Mi Hye Yu, MD, PhD

Department of Radiology, Konkuk University Medical Center, Konkuk University School of Medicine, 120-1, Neungdong-ro, Gwangjin-gu, Seoul 05030, Korea

Tel: +82-2-2030-7684 Fax: +82-2-2030-5549 E-mail: yumihye@gmail.com

This is an Open Access article distributed under the terms of the Creative Commons Attribution Non-Commercial License (http:// creativecommons.org/licenses/by-nc/4.0/) which permits unrestricted non-commercial use, distribution, and reproduction in any medium, provided the original work is properly cited.
} 
or other abnormal enhancement pattern suggestive of previous pancreatitis.

Biliary-pancreas protocol MRI with MRCP was performed with 3T unit (Skyra, Siemens, Erlangen, Germany) with gadolinium contrast for further evaluation. The pancreatic cyst showed slightly low signal intensity on T2-weighted image (Fig. 1B) and high signal intensity component within the cystic lesion comparison with pure water on T1-weighted image (Fig. 1C). On MRCP, the main pancreatic duct was not dilated. Communication between the pancreatic cyst and main pancreatic duct was not revealed. The cyst showed mild rim-enhancement without enhancing mural nodule or solid component on the dynamic scan (Fig. 1D). On DWI using a respiratorytriggered single-shot spin-echo echo-planar sequence (TR/ $\mathrm{TE}, 6400 / 54$ msec; number of average, 3), the cyst showed hyper signal intensity regardless of different b values (50, 400 , and $800 \mathrm{~s} / \mathrm{mm}^{2}$ ) and the apparent diffusion coefficient (ADC) value of the internal component which was measured about $0.67 \times 10^{-3} \mathrm{~mm}^{2} / \mathrm{s}$, while the $A D C$ of background pancreatic parenchymal was $1.13 \times 10^{-3} \mathrm{~mm}^{2} / \mathrm{s}$, suggesting the profound restriction of water molecules (Figs, $1 \mathrm{E}$ and $1 F)$. There was no area of significant signal drop at the in- and out-of-phase chemical shift imaging. Additionally, ${ }^{18} \mathrm{~F}$-Fluorodeoxyglucose (FDG) PET-CT was performed and the pancreatic cyst did not show significant FDG uptake.

During the follow-up for two years, blood tests performed and carbohydrate antigen (CA) 19-9 was increased from 21 to 68 . Therefore, he underwent the distal pancreatectomy. On surgical specimen, welldemarcated yellowish white mass was revealed (Fig. 1G). The cystic lesion was filled with keratinized material and the epithelized cell was surrounded on H\&E staining, and was pathologically confirmed as a lymphoepithelial cyst (Fig. 1H).

\section{Discussion}

Lymphoepithelial cyst is true pancreatic cyst and it is filled with keratinized material, lined by squamous epithelium, and surrounded by lymphoid tissue (6). The pathogenesis of the pancreatic lymphoepithelial cyst is no fully understood and unclear (1). There were several hypothesis regarding the histopathogenesis of the lymphoepithelial cyst as follows: 1) squamous metaplasia of the pancreatic ducts with subsequent cystic transformation; 2) ectopic pancreatic tissue included in a peripancreatic lymph node; 3) epithelial remnants with peripancreatic lymph nodes; and 4) ectopic remnants of a brachial cleft cyst that are misplaced and fused with the pancreas during embryogenesis $(11,13)$.

Lymphoepithelial cyst frequently develops in middleaged and elderly men and occurs to all parts of the pancreas with equal frequency $(12,14)$. Usually, the cyst is well-defined and exophytic off the pancreatic parenchyma. It could be presented with unilocular or multilocular form (2). Many patients with lymphoepithelial cyst have elevated serum CA19-9 level (15). The contents of the lymphoepithelial cyst may differ from serous to caseouslike depending on the degree of keratin formation

Lymphoepithelial cyst shows uniform non-enhancing low density lesion and it demonstrates wall enhancement and internal septum on CT (3-5). The lesion does not contain the enhancing solid portion within the cyst. On MRI, lymphoepithelial cyst shows a higher intensity than that of free water on T1-weighted image and lower intensity that of free water on T2-weighted image because of the containing keratinized material $(11,12,16)$. The pancreatic lymphoepithelial cyst showed higher signal intensity than that of free water on DWI (11). Restricted diffusion within the lymphoepithelial cyst is assumed to be due to the presence of viscos fluid containing keratinized material, like other squamous-lines cysts in other organs (11). Therefore, especially, the cystic lesion shows high signal intensity in the central part and iso- signal intensity in the periphery indicated wall. However, these findings should be interpreted cautiously because other pancreatic cystic neoplasm such as mucinous cystic neoplasm or intraductal papillary mucinous neoplasm can sometimes show similar signal intensity if bleeding into the cyst has occurred (17).

In conclusion, we report a case of the pancreatic lymphoepithelial cyst with imaging features on both CT and MRI. On MRI, lymphoepithelial cyst show slightly high signal intensity on T1-weighted image and slightly low signal intensity on T2-weighted image comparison with pure water, and diffusion restriction on DWI due to the its keratinized material. It is supposed that MRI features may facilitate the differential diagnosis of pancreatic cystic lesions despite the rarity of lymphoepithelial cyst. 


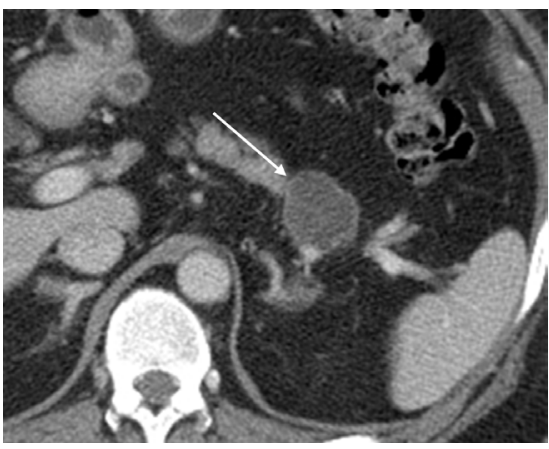

A

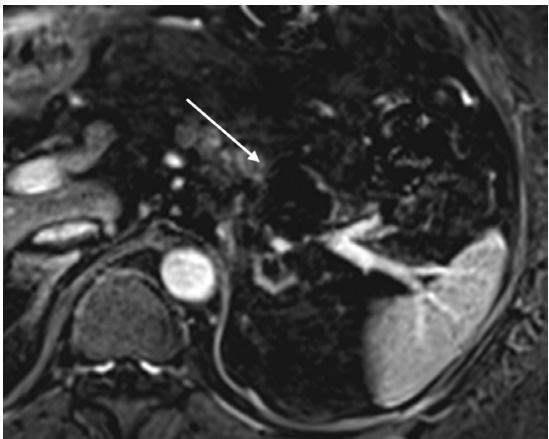

D

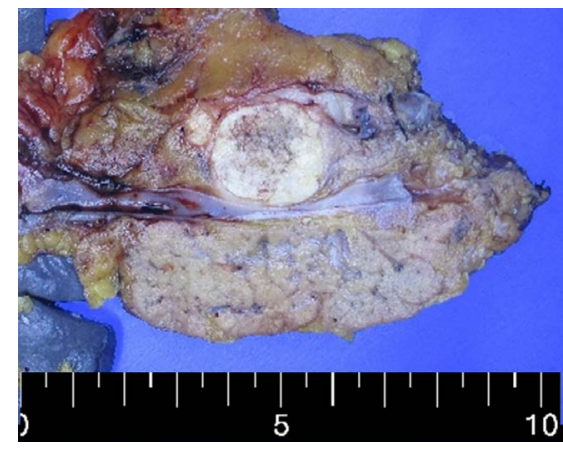

G

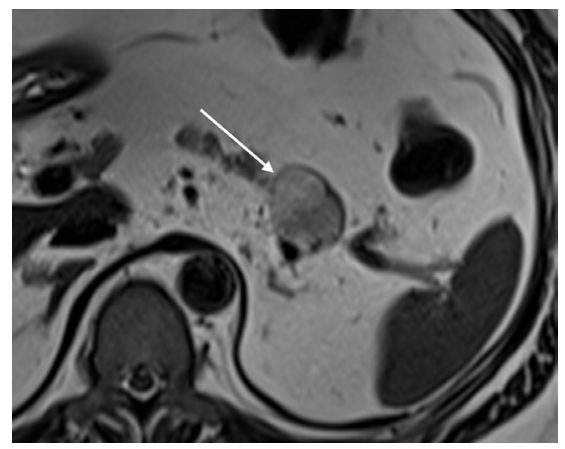

B

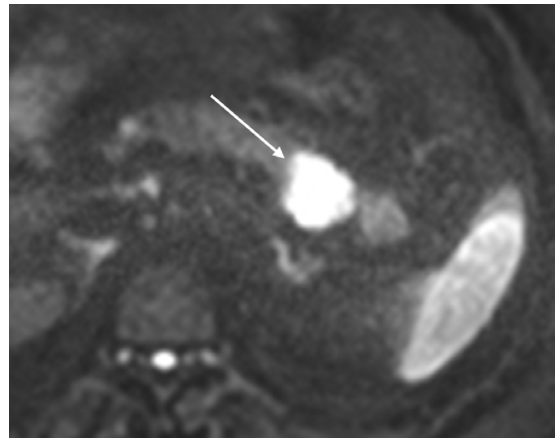

E

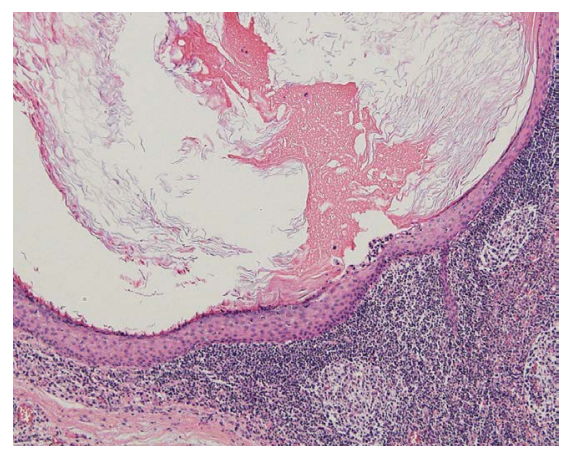

H

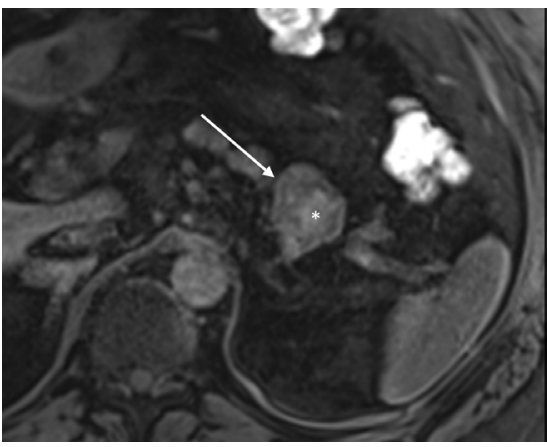

C

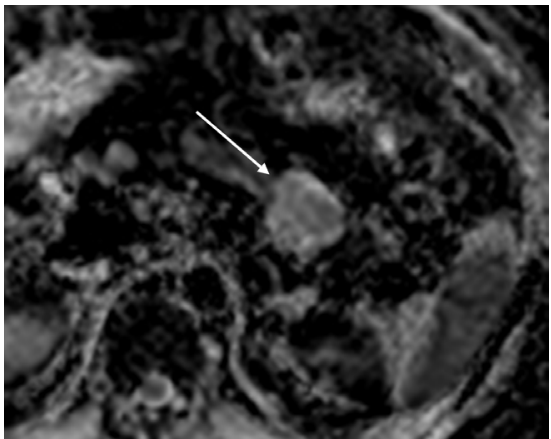

$\mathrm{F}$

Fig. 1. A lymphoepithelial cyst of the pancreas in a 53-year-old man.

A $3.3 \mathrm{~cm}$ sized, lobulated low-attenuated cystic lesion (arrow) is seen at the upper portion of the pancreas tail on contrast-enhanced CT (A). The cystic lesion reveals mild rim-enhancement and suspicious internal septa. On MRI, the pancreatic cyst (arrow) shows slightly low signal intensity on T2-weighted image comparison with pure water (B). Main pancreatic duct is not dilated. The lesion reveals internal high signal intensity component (asterisk) within the cyst (arrow) on T1-weighted image (C). On subtraction image of delayed phase (D), the cyst (arrow) shows mild rim-enhancement. Enhancing mural nodule or solid component is not seen within the cyst. On diffusion-weighted imaging (E and F), the cyst (arrow) demonstrates high signal intensity on high b-value image $\left(b=800 \mathrm{~s} / \mathrm{mm}^{2}\right)$ and the low apparent diffusion coefficient value of the internal component. After distal pancreatectomy, well-demarcated yellowish white mass is seen on gross specimen (G). The cystic lesion is filled with keratinized material and the squamous epithelium is surrounded on H\&E staining $(x 100)(H)$.

\section{References}

1. Osiro S, Rodriguez JR, Tiwari KJ, Rodriguez, II, Mathenge N, Tubbs RS, et al. Is preoperative diagnosis possible? A clinical 
and radiological review of lymphoepithelial cysts of the pancreas. JOP 2013;14:15-20.

2. Kavuturu S, Sarwani NE, Ruggeiro FM, Deshaies I, Kimchi ET, Kaifi JT, et al. Lymphoepithelial cysts of the pancreas. Can preoperative imaging distinguish this benign lesion from malignant or pre-malignant cystic pancreatic lesions? JOP 2013;14:250-255.

3. Koga H, Takayasu K, Mukai K, Muramatsu Y, Mizuguchi $Y$, Furukawa $H$, et al. CT of lymphoepithelial cysts of the pancreas. J Comput Assist Tomogr 1995;19:221-224.

4. Kim YH, Auh YH, Kim KW, Lee MG, Kim KS, Park SY. Lymphoepithelial cysts of the pancreas: CT and sonographic findings. Abdom Imaging 1998;23:185-187.

5. Fukukura Y, Inoue H, Miyazono N, Kajiya Y, Fujiyoshi F, Yano T, et al. Lymphoepithelial cysts of the pancreas: demonstration of lipid component using CT and MRI. J Comput Assist Tomogr 1998;22:311-313.

6. Adsay NV, Hasteh F, Cheng JD, Bejarano PA, Lauwers GY, Batts KP, et al. Lymphoepithelial cysts of the pancreas: a report of 12 cases and a review of the literature. Mod Pathol 2002;15:492-501.

7. Idetsu A, Ojima H, Saito K, Hirayama I, Hosouchi Y, Nishida Y, et al. Lymphoepithelial cyst of the pancreas: report of a case. Surg Today 2008;38:68-71.

8. Arumugam P, Fletcher N, Kyriakides C, Mears L, Kocher HM. Lymphoepithelial Cyst of the Pancreas. Case Rep Gastroenterol 2016;10:181-192.

9. Namba Y, Oshita A, Nishisaka T, Namba M, Sasaki T, Matsugu Y, et al. Lymphoepithelial cyst of the pancreas: A case report and summary of imaging features of pancreatic cysts. Int J Surg Case Rep 2019;55:192-195.
10. Matsubayashi H, Aikawa Y, Sugiura T, Sasaki K, Hotta K, Ono H. Pancreatic Lymphoepithelial Cyst Showing Multiple Floating Ball-like Appearances. J Gastrointestin Liver Dis 2016;25:239-242.

11. Nam SJ, Hwang HK, Kim H, Yu JS, Yoon DS, Chung JJ, et al. Lymphoepithelial cysts in the pancreas: MRI of two cases with emphasis of diffusion-weighted imaging characteristics. J Magn Reson Imaging 2010;32:692-696.

12. Terakawa H, Makino I, Nakagawara H, Miyashita T, Tajima $H$, Kitagawa $H$, et al. Clinical and radiological feature of lymphoepithelial cyst of the pancreas. World J Gastroenterol 2014;20:17247-17253.

13. Adsay NV, Hasteh F, Cheng JD, Klimstra DS. Squamous-lined cysts of the pancreas: lymphoepithelial cysts, dermoid cysts (teratomas), and accessory-splenic epidermoid cysts. Semin Diagn Pathol 2000;17:56-65.

14. Volkan Adsay N. Cystic lesions of the pancreas. Mod Pathol 2007;20 Suppl 1:S71-93.

15. Yamaguchi T, Takahashi $H$, Kagawa R, Takeda R, Sakata $S$, Yamamoto $\mathrm{M}$, et al. Lymphoepithelial cyst of the pancreas associated with elevated CA 19-9 levels. J Hepatobiliary Pancreat Surg 2008;15:652-654.

16. Shinmura R, Gabata T, Matsui O. Lymphoepithelial cyst of the pancreas: case report with special reference to imaging-pathologic correlation. Abdom Imaging 2006;31:106-109.

17. Fukunaga $N$, Ishikawa $M$, Minato T, Yamamura $Y$, Ishikura $H$, Ichimori T, et al. Lymphoepithelial cyst of the pancreas that was difficult to distinguish from branch duct-type intraductal papillary mucinous neoplasm: report of a case. Surg Today 2009;39:901-904.

\title{
췌장의 림프상피낭종: 증례 보고
}

\author{
유미혜 \\ 건국대학교 의학전문대학원 건국대학교병원 영상의학과
}

\section{초 록}

췌장의 림프상피낭종은 예후가 좋은, 드문 비악성 병변이다. 이 병변은 각질화된 물질로 채워져 있고, 편평 상피로 둘 러싸여 있으며 림프 조직으로 둘러싸여 있다. 림프상피낭종의 영상 소견은 다양하고 때로는 췌장의 다른 병변과 유사 하게 보여서, 림프상피낭종의 수술 전 영상 진단은 쉽지 않다. 이 증례 보고에서는 수술을 통해 진단된 췌장의 림프상 피낭종의 영상 소견을 자기공명영상 소견에 초점을 맞추어 보고하고자 한다. 